\title{
Efficient planning and management of determinants in Iraqi residential projects
}

\author{
Ahmed Mohammed Teen Ahmed, AnA Maria Gramescu
}

\begin{abstract}
It is important to focus on the role of modern technology in planning and managing residential projects by studying the impact of that technology on the performance determinants of projects(time, cost and quality), especially large investment projects that contribute effectively and directly to providing appropriate solutions to the housing crisis. Legislation and laws related to determinants of performance improvement in projects must be done in a way that can improve results during the implementation of those projects. The economic and environmental impacts on the performance of projects are the main factors through which all investment institutions and companies seek to achieve them to reach the goals related to achieving high marketing value and improving social goals for implementing those projects. The main determinants in project performance is quality management through several major axis related to building sustainability and improving facility management when the project is completed in addition to ease of maintenance. The safety and security of projects must be achieved in the life cycle stages of the project, starting from the start of the project and ending with the phase of removal at the end of the project life cycle, which is what modern technology will achieve and choose appropriate patterns for construction. In addition to the importance of quality on the sustainability of the construction, it is important to focus on studying the costs related to the project over the life cycle of the project, that the majority of investors and companies focus on direct costs and the importance is not given to the operational costs of the building, since the costs related to implementation constitute only a percentage It ranges between $25-45 \%$ if we take that most of the buildings have a life cycle of more than 40 years, especially residential buildings. Striking a balance between project constraints is very important not to prejudice any of the main constraints.
\end{abstract}

Index Terms - determinants, time, environment, projects management

\section{INTRODUCTION}

The main determinants of construction projects must be adapted to each other in the manner in which the main objectives of the project can be achieved by committing to achieving the project scope, table in below shows the main constraints of construction project

Ahmed Mohammed Teen Ahmed, doctoral school/ civil engineering faculty/ Ovidus University from Constanta, Constanta, Romania.

Ana Maria Gramescu, doctoral school/ civil engineering faculty/ Ovidus University from Constanta, Constanta, Romania.

\begin{tabular}{|r|c|c|c|}
\hline \multicolumn{1}{|l|}{ No } & constraint & Impact 1 & Impact 2 \\
\hline 1 & Low cost & $\begin{array}{l}\text { High } \\
\text { implementation } \\
\text { time }\end{array}$ & Low quality \\
\hline 2 & $\begin{array}{l}\text { Low } \\
\text { implementation } \\
\text { time }\end{array}$ & High cost & Low quality \\
\hline 3 & $\begin{array}{l}\text { High quality } \\
\text { High cost }\end{array}$ & $\begin{array}{l}\text { High } \\
\text { implementation } \\
\text { time }\end{array}$ \\
\hline
\end{tabular}

Table(1) impacts of constrints in residential projects

Efficient management during planning and implementation of any construction project must find balance between the main project determinants, that all investment institutions and companies undertake preliminary studies and then deep and detailed studies of the impact of the technology used to improve and balance the main determinants of the project. Usually, the financial and human resources are among the most important determinants that must be managed in an appropriate manner because most investment companies have limited resources, and therefore, taking the final decisions to choose the project must be within the process of filtering for the proposed projects after preparing documents for the project and conducting studies related to feasibility and other effects related to environmental determinants and legislations Legal in order to secure access to the main objectives of the project through several factors determined by the higher authorities that will take final decisions through the principle of priority and according to the following main determinants:

- A study that provides the resources required to implement the project and includes financial and human resources

- Examine the project-related risks by identifying potential risks and a response plan for those risks

- Priority study for projects with low costs and low human resources

- Study the priority of projects with a low implementation period

- Study high-quality projects by choosing the appropriate and modern method for construction in order to achieve high marketing value that guarantees the success of the project 
- Examine the projects that are expected to ensure that the project framework is implemented in an integrated manner

In the figure below, the main determinants through which to study them are choosing the optimal project, which is part of the knowledge makings of the foundations of project management in addition to the remaining four determinants, including: portfolio management, communications management, integration management, and procurement management

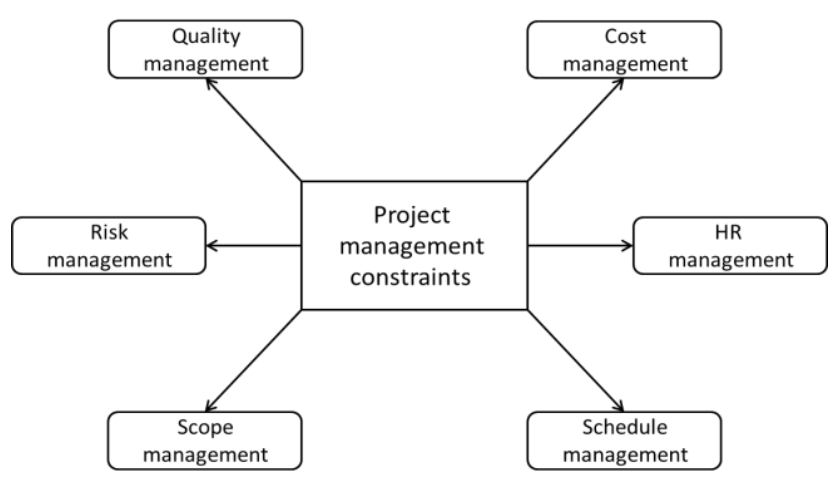

Figure (1) Main constraints in projects management

\section{THE ACTUAL NEEDS OF HOUSING UNITS IN IRAQ}

With the increase in population in Iraq, as the population for 2020 exceeded 40,000,000, according to the latest estimates [1],the shortage in a residential units exceeds 4,000,000 residential unit according to latest of iraqi ministry of construction and housing [2]. The wars that went through Iraq made him lose a lot of infrastructure, and among the great losses resulting from the wars is the great destruction in housing complexes, which greatly exacerbates the housing crisis in addition to the extinction value of $5 \%$, according to the statistics of the Ministry of Construction and Housing for housing units due to the end of a life cycle. Iraq needs to build residential unit every 40 seconds [3]. Since the problem is large and deep, solutions must be unconventional [4]. And because Baghdad is the capital of Iraq, most of the commercial centers and most of the main government departments are in them, and therefore the population density is very high compared to other cities in Iraq, as the population of the capital Baghdad is estimated at 8,000,000 [5] , and this makes the prices of housing units very high.

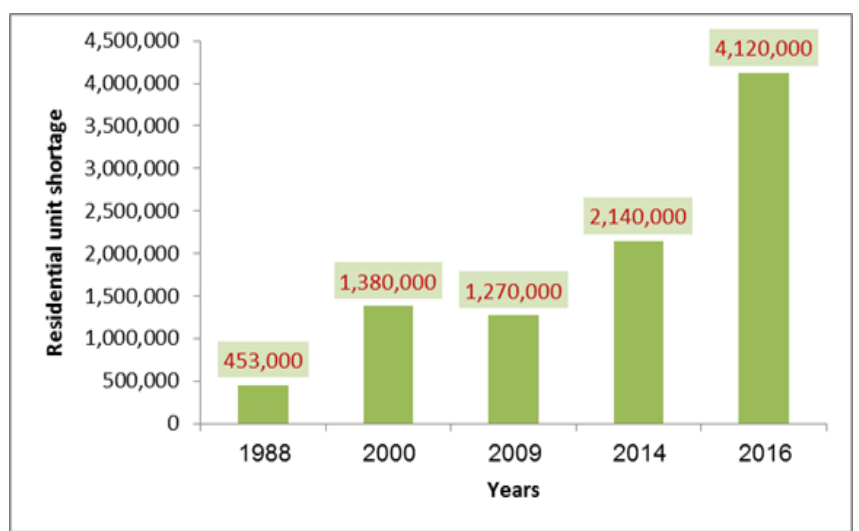

Figure (2) shortage in residential units in Iraq

\section{CRITERIA FOR CHOOSING A SUITABLE TECHNOLOGY FOR CONSTRUCTION}

The main determinants in the planning and management stages of the implementation of residential complexes must take into account the main factors in studying each proposed project, namely that the project be of good marketing value with the presence of great competition between companies and investment institutions, and this requires reducing the price of units sold to improve competition in the real estate market in addition to improving The quality through which the building life is calculated and the costs of operation and maintenance. With the increase in global warming and increasing temperatures, the environmental determinants of the legislating laws must focus on sustainable buildings that take into account environmental standards through technological methods and building materials that reduce toxic gas emissions as well as reduce pollutants resulting from energy consumption at all stages of the building life cycle by increasing Thermal insulation, reduce water and electrical consumption, and increase green areas to improve the surrounding environment. Safety and safety requirements must be a priority in the preparation of project documents and the outputs of the project implementation plan at all stages (implementation, operation, maintenance, and demolition phase at the end of the building's design life)

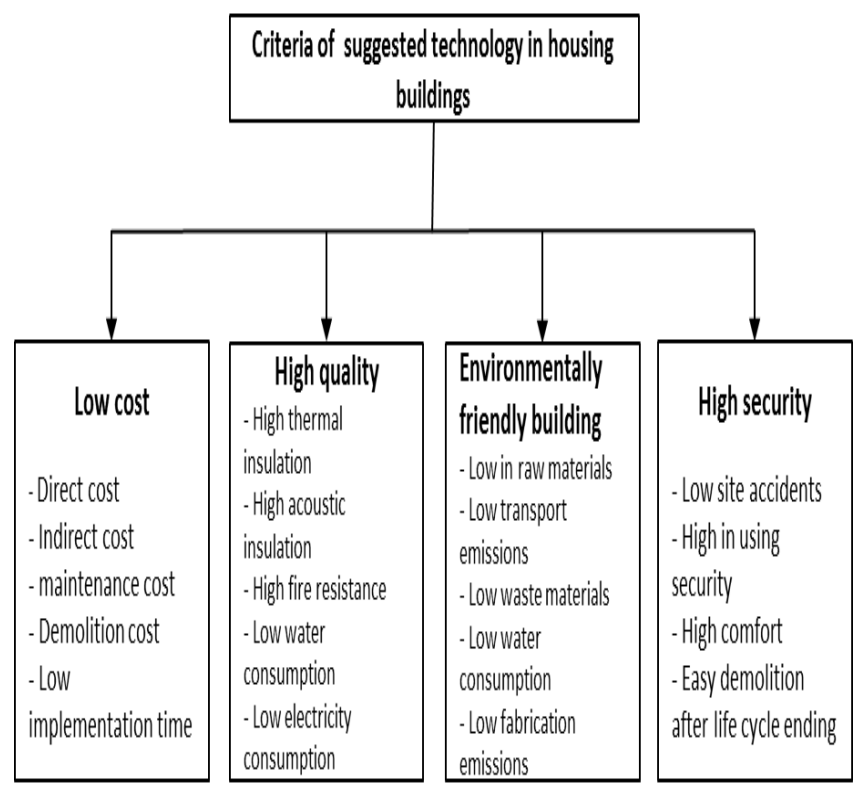

Figure (3) criteria of suggested technology in housing projects

\section{A. Costs optimization of residential units in Iraq}

The main determinants of choosing the type of technology used must be compatible with technical and environmental requirements. The most important factor that is determined by the strategy of managing housing projects is to reduce the cost to the lowest possible level to obtain radical solutions that help support the poor classes in society. The price of housing units is relatively high in the capital, Baghdad, where the price of construction depends on the method of construction used and the degree of quality of the materials as the cost is divided into three categories and on this basis it depends on the cost per square meter, as shown in the table below: 
International Journal of Engineering and Applied Sciences (IJEAS)

ISSN: 2394-3661, Volume-7, Issue-4, April 2020

\begin{tabular}{|c|c|c|c|c|}
\hline \multirow[t]{2}{*}{ No. } & \multirow[t]{2}{*}{$\begin{array}{l}\text { Construction } \\
\text { style }\end{array}$} & \multicolumn{3}{|c|}{$\begin{array}{l}\text { Construction cost of residential } \\
\text { unit }\left(\mathrm{USD} / \mathrm{m}^{2}\right)\end{array}$} \\
\hline & & Class A & Class B & Class C \\
\hline 1 & $\begin{array}{l}\text { Vertical } \\
\text { (4-10 floors) }\end{array}$ & 500 & 450 & 300 \\
\hline 2 & $\begin{array}{l}\text { Vertical } \\
\text { (2-4 floors) }\end{array}$ & 500 & 450 & 300 \\
\hline 3 & $\begin{array}{l}\text { Horizontal } \\
\text { (Separated } \\
\text { units) }\end{array}$ & 800 & 720 & 400 \\
\hline
\end{tabular}

Table (2) cost of residential unit per square meter

In addition to the purchase price of the land to be constructed, it is the most prominent element, as its price ranges between $1000-1700 \mathrm{USD} / \mathrm{m}^{2}$, and therefore the total cost of the housing unit will be as shown in the table below

\begin{tabular}{|c|c|c|c|c|c|}
\hline \multirow[t]{2}{*}{ No } & \multirow[t]{2}{*}{$\begin{array}{l}\text { Construction } \\
\text { style }\end{array}$} & \multirow[t]{2}{*}{$\begin{array}{l}\text { Land cost } \\
\left(\mathrm{USD} / \mathrm{m}^{2}\right)\end{array}$} & \multicolumn{3}{|c|}{$\begin{array}{l}\text { Construction cost of } \\
\text { residential } \\
\left(\mathrm{USD} / \mathrm{m}^{2}\right)\end{array}$} \\
\hline & & & $\begin{array}{l}\text { Class } \\
\text { A }\end{array}$ & $\begin{array}{l}\text { Class } \\
\text { B }\end{array}$ & $\begin{array}{l}\text { Class } \\
\text { C }\end{array}$ \\
\hline \multirow[t]{2}{*}{1} & \multirow{2}{*}{$\begin{array}{l}\text { Vertical } \\
\text { (4-10 floors) }\end{array}$} & 50 & 550 & 500 & 350 \\
\hline & & 100 & 600 & 550 & 400 \\
\hline \multirow[t]{2}{*}{2} & \multirow{2}{*}{$\begin{array}{l}\text { Vertical } \\
\text { (2-4 floors) }\end{array}$} & 150 & 650 & 600 & 450 \\
\hline & & 300 & 800 & 750 & 600 \\
\hline \multirow[t]{2}{*}{3} & \multirow{2}{*}{$\begin{array}{l}\text { Horizontal } \\
\text { (Separated } \\
\text { units) }\end{array}$} & 1000 & 1800 & 1720 & 1400 \\
\hline & & 1700 & 2500 & 2420 & 2100 \\
\hline
\end{tabular}

Table (3) cost of residential unit per square meter (cost of construction + cost of land)

The costs calculated in the above table include direct costs for construction that include the purchase of materials, transportation, installation and manpower costs in addition to the indirect costs represented by taxes, insurance, security and guard, but consideration must be given to the cost of the operation and maintenance ( $\mathrm{M} \& \mathrm{C}$ costs) of the building, as planning for the construction pattern and the technology used has a major impact that will determine the cost of operation and maintenance over the design life of the building. The predominant material in building housing units in Iraq is clay bricks, and it is represent more than $60 \%$ from all used materials, which cost between $\$ 100$ and $\$ 120$ per cubic meter, and it is one of the main materials in the construction industry in Iraq, and it is very expensive compared to modern alternatives, such as lightweight concrete (cellular concrete block) or foam concrete, the price of which is Less and better advantages compared to regular concrete or brick, In addition to the high thermal insulation, which is 12 times the brick insulation [6], also the absorption rate 22-29 [7] compare with $65-70 \%$ in case of traditional bricks, therefor in case of using light concrete block rather than traditional block we can to save $47 \$ / \mathrm{m}^{3}$ of total construction cost as same as the table in below

\begin{tabular}{|c|c|c|c|c|c|c|}
\hline \multirow[t]{2}{*}{ No. } & \multirow{2}{*}{$\begin{array}{l}\text { Masoniry } \\
\text { Materials }\end{array}$} & \multicolumn{4}{|c|}{ Direct construction cost per $1 \mathrm{~m}^{3}$ (USD) } & \multirow{2}{*}{$\begin{array}{c}\text { Total } \\
\text { cost(USD) } \\
\text { per } 1 \mathrm{~m}^{3}\end{array}$} \\
\hline & & Materials & manpower & transportation & installation & \\
\hline 1 & Bricks & 98 & 20 & 10 & 11 & 139 \\
\hline 2 & cellular block & 61 & 15 & 7 & 9 & 92 \\
\hline
\end{tabular}

Table (4) Direct cost comparison between traditional and modern masonry materials

\begin{tabular}{|l|l|c|c|c|}
\hline No. & \multicolumn{1}{|c|}{$\begin{array}{c}\text { Masoniry } \\
\text { Materials }\end{array}$} & $\begin{array}{c}\text { Direct cost per } 1 \mathrm{~m}^{3} \\
\text { (USD) }\end{array}$ & $\begin{array}{c}\text { Indirect cost per } 1 \mathrm{~m}^{3} \\
{[20 \% \text { of direct cost }]} \\
\text { (USD) }\end{array}$ & $\begin{array}{c}\text { Total Cost per } 1 \mathrm{~m}^{3} \\
\text { (USD) }\end{array}$ \\
\hline 1 & Bricks & 139 & 27.8 & 166.8 \\
\hline 2 & cellular block & 92 & 18.4 & 110.4 \\
\hline
\end{tabular}

Table (5) Total cost comparison between traditional and modern masonry materials

Assuming that each housing unit contains walls with a length of $100 \mathrm{~m}$ and a height of $3 \mathrm{~m}$, the ratio of the total construction size will be up to $75 \mathrm{~m} 3$ considering that the thickness of the two types is $25 \mathrm{~cm}$, and therefore the savings in the total cost of construction including the direct and indirect file will be $\$$ 4230. And if we take into consideration that the building area is $100 \mathrm{~m}^{2}$ and we apply this fact to Table No. (2) To calculate the total cost of the housing unit, we will notice the percentage reduction in the total cost of construction through the use of modern alternatives to one item of the construction materials.

\begin{tabular}{|c|c|c|c|c|c|c|c|c|}
\hline \multirow[t]{2}{*}{ No. } & \multirow[t]{2}{*}{$\begin{array}{l}\text { Construction } \\
\text { style }\end{array}$} & \multicolumn{3}{|c|}{$\begin{array}{l}\text { Total construction cost of } \\
\text { residential unit(USD) }\end{array}$} & \multirow{2}{*}{$\begin{array}{l}\text { Reducing } \\
\text { amount } \\
\text { (USD) }\end{array}$} & \multicolumn{3}{|c|}{ Reducing rate $(\%)$} \\
\hline & & Class A & Class B & Class C & & Class A & Class B & Class C \\
\hline 1 & $\begin{array}{c}\text { Vertical } \\
\text { (4-10 floors) }\end{array}$ & 50000 & 45000 & 30000 & 4230 & 8.46 & 9.4 & 14.1 \\
\hline 2 & $\begin{array}{c}\text { Vertical } \\
\text { (2-4 floors) }\end{array}$ & 50000 & 45000 & 30000 & 4230 & 8.46 & 9.4 & 14.1 \\
\hline 3 & $\begin{array}{c}\text { Horizontal } \\
\text { (Seperated } \\
\text { units) }\end{array}$ & 80000 & 72000 & 40000 & 4230 & 5.28 & 5.88 & 10.58 \\
\hline
\end{tabular}

\section{B. Optimization of quality}

Quality in projects is one of the most important determinants upon which it determines the type of project that will be chosen based on technical studies. The quality of projects determines their market value through the main elements through which the customer is attracted to these types of projects. The use of modern technological alternatives in housing projects enhances the quality of those projects, which in turn are one of the main decisive factors in solving the housing problem by increasing the design life of the building and thus this will reduce the percentage of extinction in residential buildings, which is about $5 \%$ for one year. The most important elements that modern materials and technology must contribute to are to increase the thermal and acoustic insulation in addition to reducing energy consumption and increasing the design life of the building through high performance concrete. The quality of the materials that lead to the permanence of the building and reduce the cost of operation and maintenance of the building. The use of the wall and glass insulation method reduces the consumption of electrical energy, which was unable to supply it to about $50 \%$ of the total required energy. As the 
requirements for air conditioning, especially in hot climates in Iraq, which extend for about 8 months, amount to about $72-78 \%$ of the energy used.

\section{Optimization of environmental reality}

The construction sector is one of the most important and most contributing sectors to pollution and heat emissions, as it contributes significantly to climate changes and pollution to water and air sources due to the many stages the construction industry is going through. According to the U.K. Green Building council, the consumption of building materials exceeds 400 million tons /year [8].World Green Building council mentioned that $39 \%$ from all emissions caused by construction proccess[9][10]. The consumption of raw materials included in the construction industry is not used in the construction materials industry, but there is a loss rate in those materials that exceeds $10 \%$ in the form of waste in the factory and in the work sites. construction within pre-fabricated production plants leads to a reduction in losses of waste materials by $12 \%$ [11] .Hence the importance of managing raw materials in a way that reduces emissions and pollution. According to the U.S. Green Building council, the contribution of the construction industry to the environment is very large, as shown in the countries below:

\begin{tabular}{|c|c|c|}
\hline No. & Issues & Contribution rate (\%) \\
\hline 1 & Pollution & 23 \\
\hline 2 & Climatic change & 50 \\
\hline 3 & Drinking water rate & 40 \\
\hline 4 & Landfill waste & 50 \\
\hline
\end{tabular}

Table (7) contribution of construction in global pollution according to USGBC

The rate of pollution passes in mamy stages, starting with the extraction of the raw materials involved in the construction industry, through the processes of transporting raw materials to the factory and then transportation to the work site and implementation of the project, which are many stages that must be managed in an efficient manner that guarantees reducing pollution and emissions resulting from construction processes. The manufacturing and construction procedures must be improved during the 7 stages to reduce the pollution rate, as shown in the figure below:

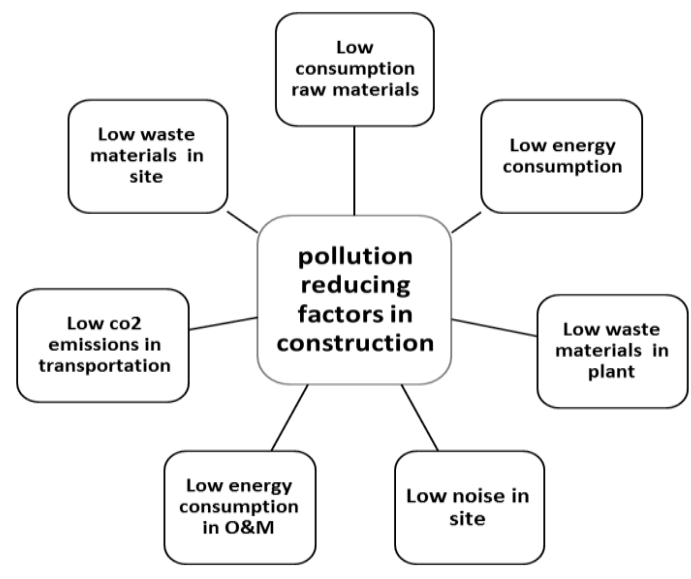

Figure (3) pollution reducing stages in construction fabrication
The use of modern construction technology reduces emissions and pollution from construction operations. The use of prefabricated building technology can reduce pollution and emissions significantly through its contribution to reduce the consumption of raw materials, reduce waste in reality, reduce emissions from energy consumption, in addition to reducing noise during the implementation of the project and at the operation period due to high sound insulation which is In line with achieving the principles of building sustainability. $10 \%$ or more saved by using prefabricated construction technology.fabrication proccesses deals with all waste material that caused by prefabricated construction and recycle all waste material to reduce the impacts of waste materials on the environment and to reduce

\section{Optimization of security}

Among the most important requirements for planning for efficient project management are the safety and security standards for the facility and the residents of those complexes, in addition to workers during the period of implementation and maintenance. According to HSE $40 \%$ of fatal injuries are caused by falling from high [12] as shown in figure below:

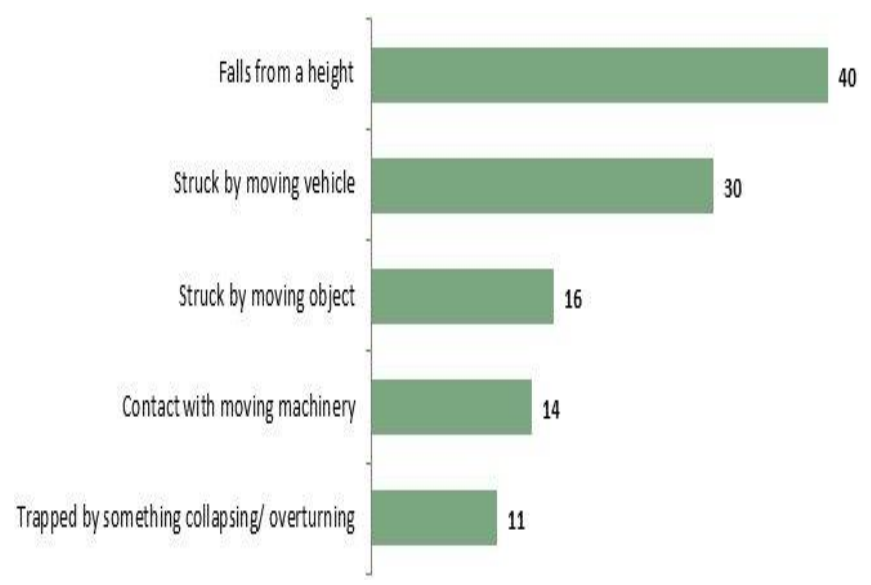

Figure (4) Main kinds of fatal accident for workers, Source: RIDDOR, 2018/19

From here, the effects related to the materials and technology proposed for the implementation of housing projects should be studied to ensure a reduction in work-related accidents, as well as a decrease in accidents related to accidents during the operation and maintenance period because the technology used in Iraq uses traditional methods in which activities related to site construction are large and use heavy blocks, and many activities of external and internal finishes (internal and external plastering) as well as the local casting of many activities related to reinforced concrete work ( foundations, columns, beams, and roofs) then thus activities need many numbers of site workers, and therefore one of the most important solutions related to reducing accidents at the site must ensure the change of the traditional technology used in construction. Prefabricated construction technology may be contributes to reduce accidents in all stages of building lifecycle as shown in the table below: 


\begin{tabular}{|c|c|c|c|c|}
\hline No. & $\begin{array}{l}\text { Life cycle } \\
\text { phase }\end{array}$ & $\begin{array}{l}\text { Potential accidents } \\
\text { resources }\end{array}$ & $\begin{array}{l}\text { Accidents reducing by } \\
\text { using prefabricated } \\
\text { technology }\end{array}$ & $\begin{array}{l}\text { Impact of proposed } \\
\text { technology on accidents } \\
\text { reducing }\end{array}$ \\
\hline \multirow{4}{*}{1} & \multirow{4}{*}{ Execution } & $\begin{array}{l}\text { Many lifting times of } \\
\text { masonry materials }\end{array}$ & Low lifting times & $\begin{array}{l}\text { Low lifting time lead to } \\
\text { reducc accidents rate }\end{array}$ \\
\hline & & Many workers in site & $\begin{array}{c}\text { Low workers in site (50- } \\
60 \% \text { ) }\end{array}$ & $\begin{array}{l}\text { Reducing of accidents by } \\
\text { reducing workers }\end{array}$ \\
\hline & & Many scaffolding & low scaffoldings uses & $\begin{array}{c}\text { Low accidents because of } \\
\text { low scaffolding uses }\end{array}$ \\
\hline & & High implementation time & Low implementation & $\begin{array}{l}\text { Low implementation time } \\
\text { lead to reduce accidents rate }\end{array}$ \\
\hline 2 & $\begin{array}{l}\text { Operation and } \\
\text { Maintenance }\end{array}$ & Low quality & $\begin{array}{c}\text { High quality (50-60years } \\
\text { lifecycle) }\end{array}$ & $\begin{array}{c}\text { Low maintenance lead to } \\
\text { low accidents }\end{array}$ \\
\hline 3 & $\begin{array}{l}\text { Demolition and } \\
\text { recycling }\end{array}$ & $\begin{array}{l}\text { Much waste materials } \\
\text { caused by demolition }\end{array}$ & Low waste materials & $\begin{array}{l}\text { The construction can be } \\
\text { dismantled easily to reduce } \\
\text { accident }\end{array}$ \\
\hline
\end{tabular}

Table (8) contribution of construction in global pollution according to USGBC

\section{CONCLUSION}

The impact of the main units of the projects is closely related to the technology used that helps in improving the management of housing projects and finding economic alternatives that reduce the cost as found in prefabricated constructions and the use of cellular concrete, which contributes to reducing the cost up to (5-10) \% of the total cost in addition to improving quality and reducing environmental damage by reducing energy consumption and reducing construction waste. The feasibility of the proposed technology is not limited to initial impacts during the planning and implementation period, but the integration of the feasibility is to improve the management of project determinations during the Operation and Maintenance period as well as the effects associated with the operations of removal and recycling of waste from buildings.

\section{REFERENCES}

[1] Al-Muheet, [online]: https://www.almuheet.net/60989/

[2] Baghdad press, [online] https://baghdadpress.org/ar/news.php?id=8938

[3] Minister deputy of Iraqi construction and housing, Al-Mada Economic journal, 2010, [online] https://www.almadasupplements.com/news.php?action=view\&id=250\#stha sh.ICZfG9GT.dpbs

[4] Luay Taha Almulla Huwish, Intisar Qadoori Jumaah ,"Some of the preferred housing

alternatives in Baghdad",Al-Handasa journal, Vol. 3, 2008, pp. 379-398

[5] Al-Muheet, [online] https://www.almuheet.net/60989/

[6] Intisar Qadoori Jumaah, Faisal Khadim , "Comparative study to employ light weight concrete"

alternative from traditional bricks in buildings partitions, Iraqi academic scientific journal,

Foundation of technical education, Vol.24, pp. A39-52, 2011

[7] Daad Mohamed Daood, Nadia Salim Esmaeil, "Processing Lightweight Aggregate to 2009

produce LightweightConcrete", Al-Rafidain Engineering, No.6, Vol.18,

[8] Jenny Snook, "How Does Construction Impact the Environment?" GOCONTRACTOR,

2017 ,

[online]

https://gocontractor.com/blog/how-does-construction-impact-the-environme nt/

[9] World Green Building Council, "Air Quality in the Built Environment", online:

https://worldgbc.org/clean-air-buildings/causes

[10] International Energy Agency, Energy Efficiency: Buildings, 2019, online:

https://www.iea.org/topics/energyefficiency/buildings/
[11] I. Nahmens,L. H. Ikuma, "Effects of Lean Construction on Sustainability of Modular 18(2), pp.

Homebuilding", Journal of Architectural Engineering, ASCE, Vol.

[12] Health and Security Executive, online: https://www.hse.gov.uk/statistics/fatals.htm

Ahmed Mohammed Teen Ahmed: student in Ovidus University, Doctoral school. MSc. In civil engineering- projects management, chef engineers in Ministry of electricity in Iraq, consultant engineer in Iraqi Engineers Association

Ana Maria Gramescu: Prof univ dr ing Grămescu Ana Maria, Supervisor doctorate dom Civil Engineering University OVIDIUS Constanta ; President of the International College of Continuing Professional Training of Experts and Specialists - SC International Expert Management, Technical expert certified by the Ministry of Justice in the specializations: resistance and stability of constructions, industrial and agricultural civil constructions, evaluation of real estate properties and works performed with EU funds, Technical expert certified by MDRAP in the field of resistance and stability of constructions; Technical expert certified by the Ministry of Culture and National Identity in the field of restoration of historical monuments; Technical expert certified by the MAA in the field of land valuations . Member of: The Romanian Committee for the History of Science and Techniques within the Romanian Academy; European Expertise \& Expert Institute; Association of Engineers Constructors Designing Structures; The Romanian Association of Criminal Sciences; The National Union of the Restoration of Historical Monuments; The Technical Expert Corps in Romania; ANEVAR Romania; AsRES China, European Real Estate Society; Americal Real Estate and Urban Economic Association. 